\title{
EFFICIENCY OF THE SYSTEMS OF BASIC TILLAGE IN THE CROP ROTATIONS ON THE IRRIGATED LANDS OF SOUTHERN STEPPE OF UKRAINE
}

\section{Maliarchuk M. P.}

\section{INTRODUCTION}

The Steppe natural and climatic zone occupies southern part of the territory of Ukraine. The area of agricultural land is 17.617 million ha, of which 14.848 million ha of arable land that is $84.28 \%$.

In geomorphological relation the territory almost fully coincides with the Black Sea lowlands.

The surface of the Steppe zone is plain, uneven in genetic and structural relation. Its southern area is situated on the territory of the Black Sea lowlands and is a slightly divided, and to the East of the river Ingul flat, with a great number of closed lowerings, plain. To the South of the Black Sea lowlands it gradually transforms into low (150-300 m) Besarab, Podil, Dnipro and Azov rises.

The surface has general incline from the North (altitude of 150-170 m) to the South (altitude of 1-10 m). Plains are disrupted by river vales with terraces and right banks with a network of gulls.

Dominant rock in the Steppe is loess, the power of which changes from 1 to $30 \mathrm{~m}$. They are heavy-clay by granulometric structure, lightly clay within the Black Sea lowlands, moderately-clay - on the Azov rise, moderately and lightly clay on the terraces of the vale.

Smooth plain relief favored to low erosion tension that provided for preservation of powerful, uniform on the great arrays clay loess cover.

The soil cover of water-dividing plateau of the Steppe on the loess rocks is represented by chernozem and chestnut soils ${ }^{1}$.

Southern arid and Dry Steppe soil and ecological subzones of the Steppe zone occupy 5 million 761 thousand agricultural lands in five regions of Ukraine and Crimea, of which arable land occupies 4 million 507 thousand ha or $78.2 \%$. The soil cover is represented by chernozem southern and chestnut soils. The main area of chernozem southern $-62.6 \%$ is occupied by model subtypes, $22.2 \%$ - micelle-carbonate, $15.1 \%$ - alkaline, $25 \%$ - eroded. The soils of the chestnut zone are divided into dark-chestnut and chestnut. The latter occupy a narrow strip along the Sivash with a total area of

\footnotetext{
${ }^{1}$ Класифікація грунтів України. К.: Аграрна наука, 2005. 299 с.
} 
219.4 thousand ha. To the north of the chestnut soils are dark-chestnut soils with a total area of 1270 thousand ha.

Experimental field studies of the Institute of Irrigated Agriculture of NAAS were carried out in the Bilozerka natural-agricultural district of Kherson region in the zone of activity of the Ingulets irrigation system. The soil cover of the district is represented by dark-chestnut soils and their complexes with solonetz. They occupy $69.7 \%$ of arable land. The soils are characterized by a developed humus profile with a thickness of $52-58 \mathrm{~cm}$, a low content of humus (1.9-2.7\%), medium and heavy-loamy granulometric composition, deflationsafe, chemical and physical properties are satisfactory ${ }^{2,3,4}$.

On the lands irrigated from the Dnipro estuary and the Ingulets River, secondary alkalination, places of salinization and flooding of the soils are manifested ${ }^{5,6,7}$.

The territory of the district is located in northern part of the Black Sea lowland on the right bank of the Dnipro River within the Upper Pliocene terrace.

Geologically, the upper terraces are composed of four horizons of loess-loam thickness of 25-30 m, dissected by 2-3 horizons of buried soils. The forests are covered by red-brown clays that lie on Neogene Pontic lime stones. Sandy and clay deposits occur between lime stones and clays.

The soil of the experimental plot is a dark-chestnut middle-loamy secondary-alkaline silt-stone one. The granulometric composition of the studied soil is mainly represented by the large dust fraction $(38.1 \%$ in the arable layer), so they are easily susceptible to erosion processes (Table 1).

Due to the fact that irrigation of the experimental plot was carried out by the waters of low mineralization with an unfavorable ratio of one - and divalent cations (irrigation waters of the Ingulets irrigation system according to the DSTU-2730-94 belong to the 2nd class - "limited suitable for irrigation"), there was observed an increased content of exchangeable sodium in the soil absorption complex of the arable layer at different systems of tillage.

${ }^{2}$ Система ведення сільського господарства Херсонської області. Херсон: «Айлант», 2004. $164 \mathrm{c}$.

${ }^{3}$ Болдырев А. И., Андрусенко И. И., Сазонова Е. П. Баланс гумуса в темно- каштановой орошаемой почве. Почвоведение. 1978. № 1. С. 67-76.

${ }^{4}$ Бондарев А. Г. Водно-физические свойства почв сухостепной зоны и приемы ее улучшения при орошении. Физические условия почвенного плодородия. Науч. тр. Почвенного ин-та им. В.В. Докучаева. Х., 1978. С. 53-60.

${ }^{5}$ Бурзі К. Е., Красутська Н. В., Синицина Н. П., Сафонова О. П. Сольовий режим грунтів Інгулецького зрошуваного масиву. Зрошуване землеробство. 1971. Вин. 12. С. 63-67.

${ }^{6}$ Левчишина Н.И. Почвы подов южных районов Днепропетровской области и их использование. Днепропетровск: Промінь, 1996. С. 44-48.

${ }^{7}$ Алиев К. А. Рациональное использование природних ресурсов при орошении. К.: Урожай, 1991. 168 с. 
Table 1

Granulometric composition of the dark-chestnut soil of the experimental field of the Institute of Irrigated Agriculture of NAAS

\begin{tabular}{|c|c|c|c|c|c|c|c|c|c|c|}
\hline \multirow{2}{*}{ 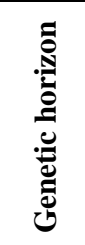 } & \multirow{2}{*}{ 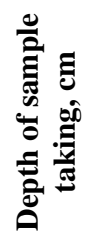 } & \multirow{2}{*}{ 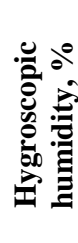 } & \multicolumn{6}{|c|}{ Fractions, mm } & \multicolumn{2}{|c|}{\begin{tabular}{|c|} 
Sum \\
of particles, \\
mm
\end{tabular}} \\
\hline & & & $1-0.25$ & $\begin{array}{c}0.25- \\
0.05\end{array}$ & $\begin{array}{l}\text { 0.05- } \\
0.01\end{array}$ & $\begin{array}{l}\text { 0.01- } \\
0.005\end{array}$ & $\begin{array}{c}0.005- \\
0.001\end{array}$ & $\begin{array}{c}<0.00 \\
1\end{array}$ & $<\mathbf{0 . 0 1}$ & $>0.01$ \\
\hline $\begin{array}{c}\mathrm{H}(\mathrm{e}) \\
\text { arable }\end{array}$ & $10-20$ & 1.06 & 0.80 & 21.44 & 38.10 & 13.95 & 4.89 & 20.82 & 39.66 & 60.34 \\
\hline Hpi & $35-45$ & 1.10 & 16 & 17.74 & 41.84 & 11.59 & 5.85 & 22.82 & 40.26 & 59.74 \\
\hline Phi $/ \mathrm{K}$ & $48-52$ & 1.08 & 0.25 & 7.94 & 40.59 & 14.26 & 10.07 & 26.89 & 51.22 & 48.78 \\
\hline $\mathrm{Pi} / \mathrm{K}$ & $55-65$ & 1.08 & 0.3 & 8.74 & 30.72 & 15.90 & 11.60 & 32.72 & 60.22 & 39.78 \\
\hline $\mathrm{P} / \mathrm{K}$ & $70-80$ & 1.07 & 0.40 & 7.10 & 31.20 & 16.20 & 12.20 & 32.90 & 61.30 & 38.70 \\
\hline
\end{tabular}

Mineralization of irrigation water during vegetation period of 2019 fluctuated within $1.538-1.708 \mathrm{~g} / \mathrm{dm}^{3}$. The content of toxic salts in the equivalents of Chloride that is used to characterize quality of water by secondary salinization of soil, in average for the studied year was $11.47 \mathrm{meq} / \mathrm{dm}^{3}$ that meets the requirements of the II class (limited suitable for irrigation). By the alkalination hazard and toxic effect on plants the irrigation water also belongs to this class. The $\mathrm{pH}$ value of the water is 8.5 .

An Important criterion of irrigation water evaluation is a ratio of Calcium to Sodium, which was 0.31 in our study, which testifies about high activity of Sodium cations.

By the results of laboratory studies Chlorides and Sulphates are dominant anions, while Sodium and Magnesium are dominant cations. That means that chemical composition of the water is determined as ChlorideSulphate Magnesium-Sodium (Table 2).

So, in accordance to the actual standard, the irrigation water belongs to II class, and it is limited suitable for irrigation by the risks of secondary salinization, alkalination and toxic effect on plants.

Analysis of the content of exchangeable cations of absorption complex at the end of vegetation testifies that the amount of exchangeable Sodium in the soil layer $0-40 \mathrm{~cm}$ increased at the expense of absorbed Calcium, the content of which relatively decreased (variant 1) under the plowless tillage methods by $1.52-3.03 \%$, and under the plowing in differentiated soil tillage in the crop rotation (variant 5 ) - by $0.76 \%$. At the tillage in the system of differentiated tillage within the crop rotation (variant 4) the content of $\mathrm{Ca}^{2+}$ was on the level with plowing (variant 1 ) and equaled to 13.2 or $67.4 \%$ from the sum of cations (Table 3). 
Therefore, irrigation with water of high mineralization with unfavorable ratio of mono- and bi- valent cations leads to changes in qualitative composition of soil absorption complex at the end of crops vegetation, where alkaline leaching of Calcium from soil was observed, accompanied by an increase in share of exchangeable Sodium and resulted in development of irrigation salinization of soil.

Soil alkalinity determines unsatisfactory water-physical properties of the arable layer. The low content of waterresistant aggregates in the arable layer of the soil complicates its cultivation in the dry conditions. Under irrigation, the surface layer over-crusts, which impedes the penetration of water into the deeper horizons of the soil. The condition of the physical maturity of the alkaline soil, which determines its suitability for cultivation in the spring, is delayed, and after cultivation - lumpy surface is formed. The clods in the dry state are strong, difficult to cultivate, in addition, in such soils at the depth of 30-35 cm, a compacted illuvial layer is formed, which impedes the penetration into the deeper layers not only for water but also for the root system of plants. Thus, dark-chestnut soils under the irrigation with the waters of the Ingulets Irrigation System require anti-erosion measures and the development and improvement of their tillage with accordance to the certain conditions of the area.

Thus, the dark-chestnut secondaryalkaline and chernozem southern moderatelywashed soils by physical, chemical and physic-chemical properties are typical soils of the meliorated agro-landscapes of Southern Steppe of Ukraine.

On the central experimental base of the Institute of Irrigated Agriculture of NAAS, a study devoted to the determination

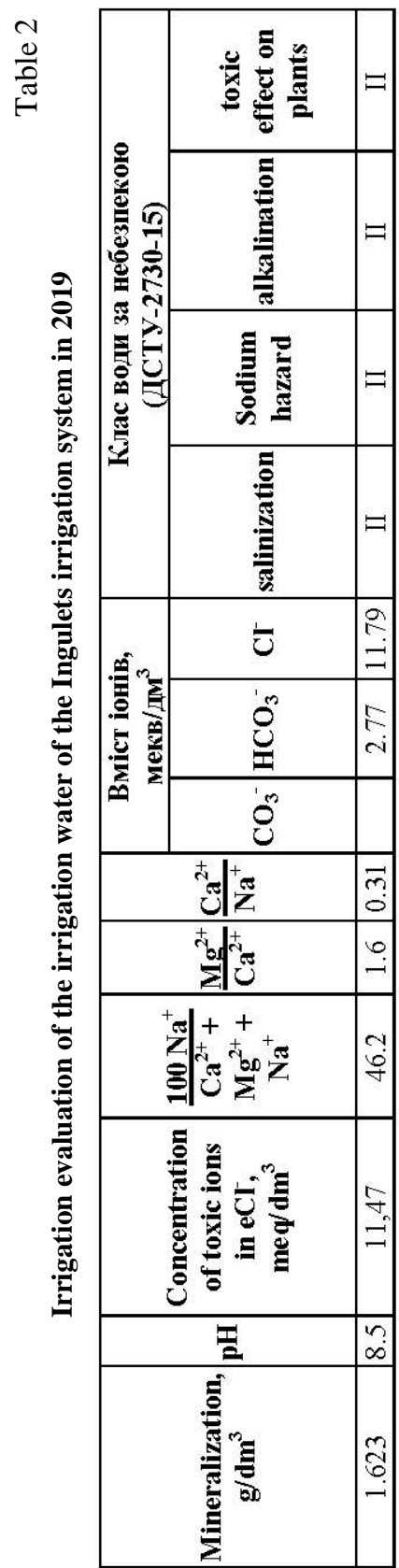


of the impact of basic tillage systems on agro physical, chemical and biological soil properties, phytosanitary conditions of crops, yields and productivity of various types of irrigated and non-irrigated crop rotations have been started since 1966.

Approbation of scientific developments and their improvement for the concrete regional conditions was carried out in research and basic farms of the Institute of Irrigated Agriculture of NAAS.

Introduction in production of prospective tillage systems in crop rotations in regard to ecological and technological classification of lands and their melìorative conditions was conducted on the irrigated lands of Kherson, Zaporizhzhia, Odesa, Mykolaiv, Dnipropetrovsk regions.

Table 3

The content of exchangeable cations in the soil layer $0-40 \mathrm{~cm}$ at different systems of basic tillage within the crop rotation on the Ingulets irrigation system (start of vegetation)

\begin{tabular}{|c|c|c|c|c|c|c|c|c|}
\hline \multirow{2}{*}{ 完 } & \multirow[t]{2}{*}{$\begin{array}{c}\text { System } \\
\text { of basic tillage }\end{array}$} & \multicolumn{3}{|c|}{$\begin{array}{c}\text { Content of } \\
\text { exchangeable } \\
\text { cations, } \\
\text { meq } / 100 \mathrm{~g} \text { of soil }\end{array}$} & \multirow{2}{*}{$\begin{array}{c}\text { Sum of } \\
\text { exchangeable } \\
\text { cations, } \\
\text { meq/ } 100 \mathrm{~g} \\
\text { of soil } \\
\end{array}$} & \multicolumn{3}{|c|}{$\begin{array}{l}\% \text { from } \\
\text { the sum of cations }\end{array}$} \\
\hline & & $\mathrm{Ca}^{2+}$ & $\mathrm{Mg}^{2+}$ & $\mathrm{Na}^{+}$ & & $\mathrm{Ca}^{2+}$ & $\mathrm{Mg}^{2+}$ & $\mathrm{Na}^{+}$ \\
\hline \multicolumn{9}{|c|}{ No fertilizers } \\
\hline 1 & Полицева & 13.2 & 5.6 & 0.48 & 19.3 & 68.5 & 29.0 & 2.5 \\
\hline 2 & Безполицева - 1 & 13.0 & 5.7 & 0.59 & 19.3 & 67.4 & 29.5 & 3.1 \\
\hline 3 & Безполицев & 12.8 & 5. & 0.65 & & 66.1 & 30.5 & 3.4 \\
\hline 4 & Диференці & 13.2 & 5. & 0.46 & 19 & 68.9 & 28.7 & 2.4 \\
\hline 5 & Диференційована-2 & 13.1 & 5.7 & 0.60 & 19.4 & 67.5 & 29.4 & 3.1 \\
\hline
\end{tabular}

$L S D_{05}$, meq/100 g of soil: 0.030 .020 .006

\section{Efficiency of ways and systems of tillage in crop rotations}

\section{on the irrigated lands}

Irrigation is the most effective measure to counteract the increasing aridity of climate, especially in southern part of the Steppe zone. Approaches to tillage in crop rotations on the irrigated lands differ significantly from those on the non-irrigated ones, and they are directed to the improvement of the water regime and ensuring ecological safety at the realization of the natural and climatic potential of the region and genetically determined productivity of varieties and hybrids of crops ${ }^{8,9}$.

${ }^{8}$ Малярчук М.П., Нижеголенко В.М., Резніченко Н.Д., Воронюк Л.А. Системи землеробства в умовах південного посушливого та сухого степу. Збірник матеріалів Міжнародної науково-практичної конференції "Наукові засади ефективного ведення степового землеробства в умовах змін клімату" 28-29 травня 2015 р. Херсон: Грінь Д.С., 2015. C. 141-145. 


\section{Fruit-changing and row crop rotations forenterprises with developed dairy and beef cattle}

Fruit-changing. Combination for a long time in fruit-changing crop rotation with the coefficient of use of irrigated arable land of 1.25 of the deep plow tillage under the row crops - corn for grain and silage, sugar and forage beetroots, soybean, vegetable crops and alfalfa, with shallow $(12-14 \mathrm{~cm})$ disk loosening under the cereals - winter wheat, winter barley, winter rye and surface $(6-8 \mathrm{~cm})$ or sowing in the previously untilled soil in the post-harvest and postmowing terms promoted nitrogen mobilization to a greater extent than the longtermed plowless tillage. At the differentiated system of tillage in crop rotation in comparison to the plowless shallow single-depth one $(12-14 \mathrm{~cm})$ the bulk density decreased by $6.3 \%$, the water permeability increased from 1.68 to $2.28 \mathrm{~mm} / \mathrm{min}$. (35.7\%), the content of waterproof units increased by $9.2 \%$.

Wrapping of plant residues or manure under plowing into the lower part of the cultivated layer in this crop rotation provided a higher level of humification process than introducing fresh organic matter into the top $(0-15 \mathrm{~cm})$ soil layer under plowless tillage systems, as evidenced by the results of the long-term experimental researches.

In the 8-field grain-herb-row crop rotation on the background of generally accepted irrigation regimes and organo-mineral fertilization system with the application of $\mathrm{N}_{180} \mathrm{P}_{120}$ and 15 tons of semi-rotten manure per 1 ha of the crop rotation contributed to the average annual increase of humus at the level of 1.28-1.57 t/ha, whereas at the long-term use (1976-2006) of the system of single-depth shallow tillage in the crop rotation the accumulation was only 0.85 t/ha ${ }^{1011} 12$.

The results of the studies, obtained in the first rotation (1966-1976) of fruit-changing crop rotation on the dark-chestnut irrigated middle-loamy soil, indicate that for 10 years of irrigation with the use of five tillage systems with a rotation of the slice to the depth of $20-22$ to $38-40 \mathrm{~cm}$ there was an increase in the content of organic matter in the soil layer of $0-40 \mathrm{~cm}$ to 111.4-111.8 t/ha with the content of $1.97 \%$, i.e. the average annual increase averaged to $0.71-0.75 \mathrm{t} / \mathrm{ha}$.

${ }^{9}$ Малярчук М.П., Вожегова Р.А., Марковська О.С. Формування систем основного обробітку грунту в агробіоценозах на меліорованих землях південної посушливої та сухо степової грунтово-екологічних підзон України Навчальний посібник. Херсон: Айлант, 2012. $180 \mathrm{c}$.

${ }^{10}$ Малярчук М.П., Писаренко П.В., Мишукова Л.С., Малярчук А.С., Котельников Д.І., Нижеголенко В.М. Ефективність мінімізованих способів основного обробітку і сівби в попередньо-необроблений грунт при вирощуванні кукурудзи на зрошуваних землях. Зрошуване землеробство: збірник наукових праць. Херсон: Айлант, 2013. Вип. 59. С. 36-38.

${ }^{11}$ Малярчук М.П. Система обробітку грунту. Наукові основи охорони та раціонального використання зрошуваних земель України. Київ: Аграрна наука, 2009. С. 299-313.

12 Малярчук М.П. Формування систем обробітку грунту в сівозмінах на меліорованих землях Південного Степу України. Посібник Українського хлібороба. 2014. 
In the next decade (1976-1986) along with systems of plow tillage we studied less energy consuming plowless tillage systems differentiated by the methods and depth. Irrigation regime, fertilization system and cultivation technologies remained unchanged. Humus content determination in the autumn of 1986 revealed that its content in the layer 0-40 cm increased in the variants of long-term differentiated by depth plowing, differentiated plowless tillage, and in the variants, where during the crop rotation plowing was interchanged with flat-cut surface and chisel tillage with one or two slotting per rotation. In the variant with plowless shallow single-depth tillage a decrease in the humus content from 111.7 to $109.8 \mathrm{t} / \mathrm{ha}$ was fixed. At the differentiated by depth plowing annual increase was $0.8 \mathrm{t}$, at surface plowless tillage $-0.67 \mathrm{t}$, at differentiated tillage with one slotting $-0.82 \mathrm{t}$, and with slotting two times $-0.84 \mathrm{t} / \mathrm{ha}$. In the variant with plowless shallow singledepth tillage the humus content decreased annually by $0.19 \mathrm{t} / \mathrm{ha}$, mainly in the soil layer $20-40 \mathrm{~cm}$.

Determination of the humus content at the end of the third crop rotation period (1996) revealed a significant difference between the studied tillage systems. At the long-term differentiated by depth plowing the humus content in the layer 0-40 cm increased to $132.0 \mathrm{t} / \mathrm{ha}$, that is the average annual increase was $1.25 \mathrm{t} / \mathrm{ha}$ of the area of the crop rotation. Differentiated plowless tillage provided the annual increase of the humus content by $0.2 \mathrm{t} /$ ha lower than on the control, and its total content in the layer $0-40 \mathrm{~cm}$ was lower by $3 \mathrm{t}$ because of less accumulation during the years of the second rotation. Single-depth shallow plowless tillage (variant 3) was also favorable for the humus accumulation. Annual average increase in the variant was $0.12 \mathrm{t} / \mathrm{ha}$ in the years of the third rotation with the total amounts of $111.0 \mathrm{t} / \mathrm{ha}$ in the layer $0-40 \mathrm{~cm}$. At the differentiated by depth systems of tillage (variants 4,5 ) the humus content was 131.0 and $126.0 \mathrm{t} / \mathrm{ha}$, respectively, with the annual increase of 1.1 and $0.8 \mathrm{t} / \mathrm{ha}$.

During the fourth crop rotation (1997-2006) the tendency in the accumulation and distribution of organic matter, that was observed during the previous years of the study by the systems of tillage, saved, at the same time, the increase tempo grew lower, in particular, at the single-depth shallow plowless tillage (variant 3 ) it was $0.8 \mathrm{t} / \mathrm{ha}$. At the differentiated by depth plow and plowless systems of tillage it was, respectively, 1.57 and $1.14 \mathrm{t} / \mathrm{ha}$. Higher tempo of humus accumulation in comparison to plowless tillage $(1.28 \mathrm{t} / \mathrm{ha})$ remained in the variant with differentiated tillage including one slotting per the rotation. During the fifth rotation (2007-2016), alfalfa and multicomponent herb mixtures for green manure in the post-harvest period were excluded from the crop rotation, and the entire leaf-stem mass of the crop rotation was used for fertilization. As a result, the tempo of humus accumulation over this 10-year time span decreased in all the variants of the experiment and averaged 
to $0.1-0.3 \mathrm{t} / \mathrm{ha}$, with the highest rate in the variant of the differentiated basic tillage system, where differentiated by depth plowless methods are interchanged with one slotting for the crop rotation on the depth of $38-40 \mathrm{~cm}$ during the rotation (Fig. 1).

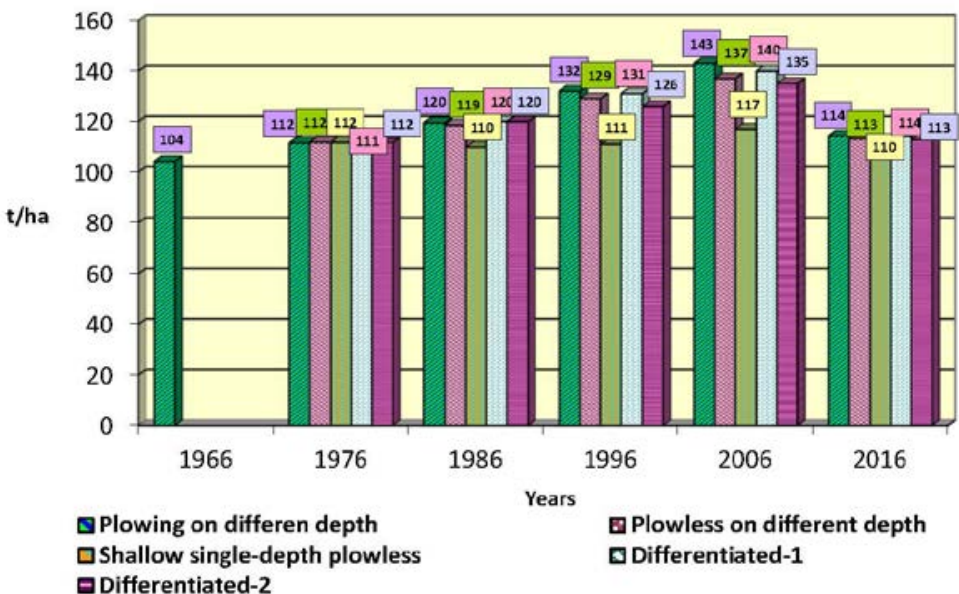

Fig. 1 Dynamics of the humus content in the 0-40 cm layer of dark-chestnut soil under different systems of basic tillage in 8-field fruit-changing irrigated crop rotation for the period of 1966-2016, t/ha

In general, experimental studies of the efficiency of different systems of basic tillage of dark-chestnut soil provided the possibility to find out that the highest productivity of the eight-crop fruit-changing rotation is provided by the differentiated system of basic tillage, in which the plowing to the depth of 20-22 to 30-32 cm under the row crops inter-changes with plowless tillage to the depth of 12-16 cm under winter wheat and spring barley on the background of one slotting $(38-40 \mathrm{~cm}$ ) for the rotation under barley with alfalfa.

The use of the differentiated basic tillage system, at the insignificant decrease in the cultivation technologies expenditures, increased the cost recovery by $9.4 \%$ due to the increase in the crop rotation productivity up to $13.0 \mathrm{t} / \mathrm{ha}$ of forage units against $11.5 \mathrm{t} / \mathrm{ha}$ of forage units at the plowless single-depth shallow (12-14 cm) system of basic tillage (Table 4).

Row forage. The increase of the coefficient of arable land use in the irrigated crop rotations up to 1.75 at the expense of inter-crops in early spring, post-mowing and post-harvest periods makes it possible to increase the efficiency of irrigated hectare and to obtain more products at the same costs for the construction of irrigation network and its exploitation, as well as provides additional accumulation of organic matter, which improves the physical and chemical properties of the soil and activates beneficial 
microorganisms activity. Owing to inter-crops of leguminous and cabbage crops, nitrogen reserves are increasing, and the weediness of the following crops is reduced.

In the arable soil layer, after sowing of the inter-crops, where the recommended irrigation regime has been maintained, there is sufficient water for its qualitative preparation to sowing. The decisive value for the crops cultivation in the post-mowing and post-harvest periods is not the depth, but the quality of pre-sowing tillage, that is, good seed wrapping and sufficient compaction of the seed bed for better provision with water of the crops with large seeds.

Taking into account that their growth and development is limited in time, it is advisable to observe these conditions. Compliance with the necessary agrotechnical requirements enables the use of combined tillage aggregates for simultaneous tillage, sowing and rolling.

As a result of the introduction of differentiated system of basic tillage in the 4-field row crop rotation with the coefficient of use of irrigated arable land of 1.75, the high efficiency of its saturation with early spring, postmowing and post-harvest crops has been established.

Table 4

Productivity of 8-field fruit-changing crop rotation at irrigation under the different systems of basic tillage of dark-chestnut soil of the experimental field of the Institute of Irrigated Agriculture of NAAS

\begin{tabular}{|l|c|c|c|c|c|}
\hline \multirow{2}{*}{\multicolumn{1}{|c}{ Crop of the rotation }} & \multicolumn{5}{c|}{$\begin{array}{c}\text { Productivity by the systems, t/ha } \\
\text { of forage units }\end{array}$} \\
\cline { 2 - 6 } & $\mathbf{1}$ & $\mathbf{2}$ & $\mathbf{3}$ & $\mathbf{4}$ & $\mathbf{5}$ \\
\hline $\begin{array}{l}\text { Annual crops for green } \\
\text { forage+alfalfa (hay) }\end{array}$ & 13.6 & 13.1 & 12.3 & 13.6 & 13.2 \\
\hline Alfalfa of the 2 ${ }^{\text {nd }}$ year (hay) & 12.1 & 12.1 & 12.2 & 12.0 & 12.1 \\
\hline Alfalfa of the 3 ${ }^{\text {nd }}$ year (hay) & 9.8 & 8.4 & 8.4 & 9.7 & 8.3 \\
\hline $\begin{array}{l}\text { Winter wheat+post-harvest } \\
\text { (grain+green mass) }\end{array}$ & $\frac{6,9}{39,2}$ & $\frac{71,5}{402}$ & $\frac{70,8}{376}$ & $\frac{71,2}{400}$ & $\frac{70,3}{399}$ \\
\hline Sugar-beet & 6.6 & 5.9 & 5.5 & 6.9 & 6.6 \\
\hline Corn for silage & 45.6 & 42.3 & 38.3 & 46.6 & 47.1 \\
\hline $\begin{array}{l}\text { Winter wheat+post-harvest } \\
\text { (grain+green mass) }\end{array}$ & $\frac{65,9}{492}$ & $\frac{70,2}{517}$ & $\frac{72,9}{505}$ & $\frac{68,3}{499}$ & $\frac{67,1}{482}$ \\
\hline Grain corn & 8.9 & 7.7 & 7.5 & 9.1 & 8.7 \\
\hline $\begin{array}{l}\text { Crop rotation productivity, } \\
\text { forage units }\end{array}$ & 12.8 & 11.8 & 11.5 & 13.0 & 12.6 \\
\hline
\end{tabular}

Note: 1-plowing at different depth, 2-plowless at different depth, 3-shallow singledepth plowless, 4-differentiated-1 with plowing under the row crops and one slotting per rotation, 5-differentiated-2 with plowing under the row crops 
The loosening effect of the root system, the protective effect of the vegetative mass of plants in the spring and summer period and the effect of post-harvest residues of inter-crops, directed to the soil improvement, contributed to the reduction of the bulk density of dark-chestnut soil in the layer of $0-30 \mathrm{~cm}$ from 1.28 to $1.14-1.19 \mathrm{~g} / \mathrm{cm}^{3}$, or $11.0-8.0 \%$ to the optimum values for cereals and row crops.

The highest yield, and correspondingly, the productivity of the crop rotation, was provided by the differentiated tillage, in which the deep plowing under sugar-beet inter-changes with the plowless shallow and surface tillage for intermediate early spring mixtures, winter barley, post-mowing crops of grain corn and sunflower, with sowing of corn for forage in the previously unprepared soil after winter barley (Table 5).

Table 5

Productivity of 4-field row forage crop rotation at irrigation under the different methods of basic tillage of dark-chestnut soil of the experimental field of the Institute of Irrigated Agriculture of NAAS

\begin{tabular}{|c|c|c|c|c|c|c|}
\hline \multirow{2}{*}{ 党 } & \multirow{2}{*}{ Crop } & \multicolumn{4}{|c|}{ Productivity by the systems, t/ha } & \multirow{2}{*}{$\begin{array}{c}\mathrm{LSD}_{05}, \\
\text { t/ha }\end{array}$} \\
\hline & & 1 & 2 & 3 & 4 & \\
\hline \multirow{2}{*}{1} & Annual herb mixtures & 32.4 & 33.9 & 33.9 & 34.5 & 2.9 \\
\hline & Post-mowing sunflower (seed) & 3.0 & 2.8 & 3.0 & 3.2 & 0.24 \\
\hline \multirow{2}{*}{2} & Annual herb mixtures & 31.1 & 31.4 & 32.3 & 32.5 & 2.6 \\
\hline & Post-mowing corn for forage & 38.9 & 40.6 & 42.6 & 40.9 & 3.0 \\
\hline \multirow[b]{2}{*}{3} & Winter barley (grain) & 4.2 & 4.4 & 4.4 & 4.2 & 0.3 \\
\hline & $\begin{array}{l}\text { Post-harvest corn for green } \\
\text { forage }\end{array}$ & 37.5 & 41.1 & 40.8 & 39.3 & 3.0 \\
\hline \multirow[t]{2}{*}{4} & Sugar-beet & 52.0 & 53.3 & 56.1 & 55.8 & 3.6 \\
\hline & $\begin{array}{l}\text { Crop rotation productivity, } \mathrm{t} / \mathrm{ha} \\
\text { of forage units }\end{array}$ & 13.8 & 14.24 & 14.7 & 14.6 & - \\
\hline
\end{tabular}

Note: 1-plowing at different depth, 2-plowless at different depth, 3-differentiated with slotting, 4-differentiated with plowing under the row crops.

\section{Row crop rotations for the enterprises working} for the industrial processing

Row short crop rotations. During 2007-2019, on the background of continuous application of five basic tillage systems and three organo-mineral fertilizer systems, using as the fertilizer of leaf-stem mass of the crops of the crop rotation, the least experimentally studied and scientifically substantiated row crop rotations were investigated, which were found at the enterprises specializing in the production of cereals and industrial crops for industrial processing. Today, among the total are of the irrigated lands of 510 thousand ha, 265 thousand ha are covered by the row crops, which is $52.0 \%$. 
In these newly established large-scale enterprises, where there is no livestock industry, short crop rotations with soybean, corn for grain and sunflower have the priority. Cereal and perennial herbs are not usually cultivated there, they occupy just about $10-15 \%$ of the croplands.

Crops, which are the part of row crop rotations, have different requirements for agro-physical properties and nutritional regimes, which are formed mainly under the influence of basic tillage and fertilization systems.

Nowadays, leaf-stem and root post-harvest residues of crops are the main source of fresh organic matter for the soil, which under the activity of microorganisms; oxidation and polymerization processes are transformed into new substances that are contained neither in the input organic residues, nor in microorganisms. According to the results of the research, it is established that on the non-fertilized background every year 4.0 to 4.8 tons of post-harvest residues are incorporated into the soil per 1 ha of the crop rotation area, on the background $-\mathrm{N}_{82.5} \mathrm{P}_{60}$ from 7.4 to 8.3 tons, and on the background of $\mathrm{N}_{120} \mathrm{P}_{60}$ application from 7.5 to 9.4 t/ha.

Calculations of humus income into the soil from incorporated postharvest residues under the different basic tillage systems and nutrition background indicate that a negative humus balance is formed for all tillage systems, while the highest values were at plowless single-depth shallow $0.33 \mathrm{t} / \mathrm{ha}$ and the smallest $-0.16 \mathrm{t} / \mathrm{ha}$ for the differentiated- 1 tillage with slotting on the depth of 38-40 cm once per rotation.

On the fertilized backgrounds with the application of $\mathrm{N}_{82.5} \mathrm{P}_{60}$ and $\mathrm{N}_{120} \mathrm{P}_{60}$ there was an increase in humus content. In the variants of multi-depth plow and differentiated- 1 systems of the basic tillage, the increase of humus content was $+0.78 \mathrm{t} / \mathrm{ha}$, while under the plowless on different depth it was lower by $14.1 \%$ and was $+0.68 \mathrm{t} / \mathrm{ha}$.

At the systems of single-depth shallow plowless tillage and the differentiated-2, the humus content increase was also positive, while it was lower in comparison to the control (differentiated plowing) by 51.3 and $38.5 \%$, respectively, at +0.38 and $+0.48 \mathrm{t} / \mathrm{ha}$.

To compensate the uptake of mineral nutrients with the crops, there was an input of total nitrogen, phosphorus and potassium into the soil with root and leaf residues. Thus, on a non-fertilized background, with basic plow tillage on the different depth (control), there was an income to the soil of $\mathrm{N}-21.8 ; \mathrm{P}_{2} \mathrm{O}_{5}-10.9 ; \mathrm{K}_{2} \mathrm{O}-26.7 \mathrm{~kg}$, and for the differentiated -1 with one slotting on 38-40 cm for the rotation $-\mathrm{N}-22 \mathrm{~kg} ; \mathrm{P}_{2} \mathrm{O}_{5}-11.0 ; \mathrm{K}_{2} \mathrm{O}-26.4 \mathrm{~kg}$ per hectare of the crop rotation area. A similar tendency was observed on the fertilized backgrounds, while at the same time the indexes of mineral nutrition income were significantly higher.

At the application of the dose of $\mathrm{N}_{82.5} \mathrm{P}_{60}$, the income of nitrogen, phosphorus and potassium into the soil with plant residues was $70-80 \%$ higher than on the non-fertilized background. 
Nitrogen, phosphorus and potassium income into the soil at the doses of $\mathrm{N}_{120} \mathrm{P}_{60}$ application averaged at the plow tillage on different depth to, respectively: $\mathrm{N}-42.6 \mathrm{~kg} / \mathrm{ha} ; \mathrm{P}_{2} \mathrm{O}_{5}-21.3$ and $\mathrm{K}_{2} \mathrm{O}-51.1 \mathrm{~kg} / \mathrm{ha}$, that is $91.4-95.4 \%$ more than in the non-fertilized background (control).

At the multi-depth plowless and differentiated-1 systems of the basic tillage, the reduction of mineral nutrition inputs in comparison to the control was not significant and averaged to $1.8 \%, 1.5$ and $1.7 \%$.

Only under the system of single-depth shallow plowless tillage with its long application in the crop rotation and on all the fertilization backgrounds, there was a significant decrease in the income of all mineral nutrients in comparison to the system of plow tillage on different depth.

In general, the application of mineral fertilizers and the use of postharvest (leaf and stem) residues as fertilizers contributed to the creation of different levels of content of available forms of mineral nutrients at the beginning of the spring regrowth of winter crops and emergence of spring cereals and industrial crops seedlings.

At the non-fertilized background with the use of post-harvest residues as a fertilizer at the beginning of vegetation of the crops of the crop rotation, the highest content of mobile mineral nutrition compounds was in the variant of the plowing basic tillage system: nitrates $29.8 \mathrm{mg} / \mathrm{kg}$ of soil, mobile phosphorus of 31.8 and exchangeable potassium of $289 \mathrm{mg} / \mathrm{kg}$ of soil.

The application of mineral fertilizers with the dose of $\mathrm{N}_{82.5} \mathrm{P}_{60}$ ensured the increase in the content of all the elements of mineral nutrition, while at the same time the advantage remained at the system of differentiated by the depth plowing.

The highest nitrate content of $68.4 \mathrm{mg} / \mathrm{kg}$ of soil, mobile phosphorus of 46.4 and exchangeable potassium of $358 \mathrm{mg} / \mathrm{kg}$ of soil was formed under the application of mineral fertilizers with the dose of $\mathrm{N}_{120} \mathrm{P}_{60}$ per hectare of the crop rotation area under the multi-depth plow system of tillage.

Multi-depth plowless and differentiated tillage systems provided close performance with the multi-depth plow tillage system, and only the singledepth shallow plowless loosening system led to a significant decrease in the content of available mineral nutrients in the soil layer of $0-40 \mathrm{~cm}$ at the beginning of the spring vegetation of the crops of the rotation.

Before the harvesting, the nitrate content of the soil decreased on all the nutritional backgrounds, while at the same time the smallest indexes were on the non-fertilized background.

It should be mentioned that the basic tillage affected the content of mobile phosphorus and exchangeable potassium. It was the lowest at the plowless shallow single-depth tillage and reached $27.9-38.3$ and $259-315 \mathrm{mg} / \mathrm{kg}$ at the beginning of the growing season and $18.7-21.9$ and $214-254 \mathrm{mg} / \mathrm{kg}$ of the soil, respectively, before the harvesting. Before the harvesting, their content reduced and remained within the range of moderate supply. 
Analyzing the crop productivity data in the crop rotation on the nonfertilized background it was found that its highest values, expressed in the grain units per 1 ha of the crop rotation area, were obtained at the plowing tillage on the different depth -4.00 , and differentiated-1 -4.35 t/ha of grain units.

Under the use of the different-depth plowless tillage and the differentiated-2 basic tillage, slightly lower yields of grain units of 3.74 and $3.60 \mathrm{t} / \mathrm{ha}$ were obtained. A significant decrease in productivity by 30.7 and $32.5 \%$ in comparison to the control was observed in the variant of shallow single-depth plowless tillage.

The productivity of the crops by the variants of the ways and depth of the basic tillage at the application of mineral fertilizers with the dose of $\mathrm{N}_{82.5} \mathrm{P}_{60}$ increased to $116.2 \%$, and the increase of the dose of fertilizers to $\mathrm{N}_{120} \mathrm{P}_{60}$ ensured its raise to $140.8 \%$, compared to the non-fertilized backgrounds.

The increase of the dose of mineral fertilizers on the background with the application of $\mathrm{N}_{120} \mathrm{P}_{60}$ was favorable for the growth of productivity by $16.0 \%$ of grain units in comparison to the $\mathrm{N}_{82.5} \mathrm{P}_{60}$ nutritive background.

Analyzing productivity of the crop rotation by the yield of grain units per hectare of the crop rotation by the backgrounds of mineral nutrition it is necessary to note that the highest out pay of fertilizers was at plow and plowless tillage on different depth and differentiated-1 tillage and was, respectively, $27.7-29.0 ; 27.3-28.2$ and $30.2-30.3 \mathrm{~kg} / \mathrm{kg}$ of a.s.

At the shallow single-depth and differentiated-2 tillage it fluctuated within 20.6 to $21.3 \mathrm{~kg} / \mathrm{kg}$ of a.s., respectively. Increasing the dose of fertilizers from $\mathrm{N}_{82.5} \mathrm{P}_{60}$ to $\mathrm{N}_{120} \mathrm{P}_{60}$ provided the increase in fertilizers out pay by $1.3 \mathrm{~kg} / \mathrm{kg}$ of a.s. at plow tillage on different depth.

Main agrotechnical measure, on which crop cultivation technologies are based, is basic tillage, which is conducted on the maximum depth. In the structure of the expenditures for cultivation its share varies from 2 to $10 \%$, while at the same time it largely depends on the productivity of most crops on irrigated lands. Assessing the effectiveness of low-cost, shallow and multidepth soil tillage systems in the crop rotation, it should be noted that having provided significant cost savings for their implementation, they have little impact on the overall expenditures for crop production on the whole. So, if on a non-fertilized background at the systems of different-depth plowing basic tillage (control), the expenditures for cultivation technology averaged to 9.6 thousand UAH per hectare of the crop rotation area, then for the systems of different-depth plowless tillage and differentiated-1 with one slotting per the rotation and differentiated-2 with one plowing per the rotation (variants 2 , $4,5)$, they were less by $1.1,0.9$ and $2.4 \%$, respectively.

At the single-depth shallow plowless tillage system (variant 3), expenditures have decreased by 3.3\%. The cost of gross production per hectare of the crop rotation area for various plowing systems on the non-fertilized background 
was 18.3 thousand UAH. In the variant of the differentiated-1 basic tillage system, it was higher and averaged to 19.1 thousand UAH, or increased by $4.2 \%$ with a profitability level of 89.5 and $99.3 \%$, respectively.

The lowest payback of crop cultivation technology in the irrigated crop rotation was on the unfavorable background of the single-depth shallow plowless tillage system, with a gross output of 12.1 thousand UAH, which is lower than the control by $33.8 \%$ with a profitability level of $29.8 \%$.

\section{CONCLUSIONS}

On the dark-chestnut soils in the zone of activity of the Ingulets irrigation system at the irrigation with water of high mineralization we recommend:

1. In the farms with developed animal husbandry it is advisable to introduce fruit-changing crop rotations with the coefficient of irrigated arable land use of 1.25-1.75 and use differentiated systems of tillage, when deep plowing under row crops and perennial grasses (corn, soybean, beet-root, alfalfa) is interchanged with plowless shallow tillage under cereal crops and sowing crops in the unprepared soil in interim terms (early spring, aftermowing, and after-harvesting mixtures of herbs for green forage).

2. In the farms aimed on the production for industrial processing it is advisable to use row crop rotations saturated with liquid high-profitable crops (corn, soybean, sunflower, rape, and winter wheat), leaf-stem mass should be used for a green manure, and apply differentiated tillage with plowing (from $18-20$ to $28-30 \mathrm{~cm})$ under rape and sunflower, disk-chisel tillage $(12-14+$ $38-40$ under corn) and shallow (10-12 and 12-14 cm) disk tillage under winter wheat and barley.

Prolonged use of differentiated systems of basic tillage in crop rotation at irrigation has ensured, on the background of application of different doses of mineral fertilizers, the formation of the highest level of productivity. Not significant decrease was observed in the variants of different-depth chisel and single-depth shallow disk loosening, mainly due to the yield of corn grain.

Sowing in untreated soil over 10 years of the research has led to a significant decrease in the crop yields and the crop rotation productivity in general.

\section{REFERENCES}

1. Класифікація грунтів України. К.: Аграрна наука, 2005. 299 с.

2. Система ведення сільського господарства Херсонської області. Херсон: «Айлант», 2004. 164 с.

3. Болдырев А. И., Андрусенко И. И., Сазонова Е. П. Баланс гумуса в темно-каштановой орошаемой почве. Почвоведение. 1978. № 1. C. 67-76. 
4. Бондарев А. Г. Водно-физические свойства почв сухостепной зоны и приемы ее улучшения при орошении. Физические условия почвенного плодородия. Науч. тр. Почвенного ин-та им. В.В. Докучаева. X., 1978. C. 53-60.

5. Бурзі К. Е., Красутська Н. В., Синицина Н. П., Сафонова О. П. Сольовий режим грунтів Інгулецького зрошуваного масиву. Зрошуване землеробство. 1971. Вин. 12. С. 63-67.

6. Левчишина Н.И. Почвы подов южных районов Днепропетровской области и их использование. Днепропетровск: Промінь, 1996. С. 44-48.

7. Алиев К. А. Рациональное использование природних ресурсов при орошении. К.: Урожай, 1991. 168 с.

8. Малярчук М.П., Нижеголенко В.М., Резніченко Н.Д., Воронюк Л.А. Системи землеробства в умовах південного посушливого та сухого степу. Збірник матеріалів Міжнародної науково-практичної конференції «Наукові засади ефективного ведення степового землеробства в умовах змін клімату» 28-29 травня 2015 р. Херсон: Грінь Д.С., 2015. С. 141-145.

9. Малярчук М.П., Вожегова Р.А., Марковська О.С. Формування систем основного обробітку грунту в агробіоценозах на меліорованих землях південної посушливої та сухо степової грунтово-екологічних підзон України Навчальний посібник. Херсон: Айлант, 2012. 180 с.

10. Малярчук М.П., Писаренко П.В., Мишукова Л.С., Малярчук А.С., Котельников Д.І., Нижеголенко В.М. Ефективність мінімізованих способів основного обробітку i сівби в попередньо-необроблений грунт при вирощуванні кукурудзи на зрошуваних землях. Зрошуване землеробство: збірник наукових праць. Херсон: Айлант, 2013. Вип. 59. С. 36-38.

11. Малярчук М.П. Система обробітку грунту. Наукові основи охорони та раціонального використання зрошуваних земель України. Київ: Аграрна наука, 2009. С. 299-313.

12. Малярчук М.П. Формування систем обробітку грунту в сівозмінах на меліорованих землях Південного Степу України. Посібник Українського хлібороба. 2014.

\section{Information about the author: Maliarchuk M. P.,} Doctor of Agricultural Science, Senior Researcher,

Chief Researcher Institute of Irrigated Agriculture of the National Academy of Agrarian Sciences of Ukraine Kherson, Naddnipryanske, 73483, Ukraine 